\title{
Molecular phylogeny of the bivalve superfamily Galeommatoidea (Heterodonta, Veneroida) reveals dynamic evolution of symbiotic lifestyle and interphylum host switching
}

Ryutaro Goto ${ }^{1,2^{*}}$, Atsushi Kawakita ${ }^{3}$, Hiroshi Ishikawa ${ }^{4}$, Yoichi Hamamura ${ }^{5}$ and Makoto Kato ${ }^{1}$

\begin{abstract}
Background: Galeommatoidea is a superfamily of bivalves that exhibits remarkably diverse lifestyles. Many members of this group live attached to the body surface or inside the burrows of other marine invertebrates, including crustaceans, holothurians, echinoids, cnidarians, sipunculans and echiurans. These symbiotic species exhibit high host specificity, commensal interactions with hosts, and extreme morphological and behavioral adaptations to symbiotic life. Host specialization to various animal groups has likely played an important role in the evolution and diversification of this bivalve group. However, the evolutionary pathway that led to their ecological diversity is not well understood, in part because of their reduced and/or highly modified morphologies that have confounded traditional taxonomy. This study elucidates the taxonomy of the Galeommatoidea and their evolutionary history of symbiotic lifestyle based on a molecular phylogenic analysis of 33 galeommatoidean and five putative galeommatoidean species belonging to 27 genera and three families using two nuclear ribosomal genes (18S and 285 ribosomal DNA) and a nuclear (histone H3) and mitochondrial (cytochrome oxidase subunit I) protein-coding genes.
\end{abstract}

Results: Molecular phylogeny recovered six well-supported major clades within Galeommatoidea. Symbiotic species were found in all major clades, whereas free-living species were grouped into two major clades. Species symbiotic with crustaceans, holothurians, sipunculans, and echiurans were each found in multiple major clades, suggesting that host specialization to these animal groups occurred repeatedly in Galeommatoidea.

Conclusions: Our results suggest that the evolutionary history of host association in Galeommatoidea has been remarkably dynamic, involving frequent host switches between different animal phyla. Such an unusual pattern of dynamic host switching is considered to have resulted from their commensalistic lifestyle, in which they maintain filter-feeding habits even in symbiotic habitats. The results of the molecular phylogenetic analysis did not correspond with the current taxonomic circumscription. Galeommatidae and Lasaeidae were polyphyletic, and Basterotia, which is traditionally assigned to Cyamioidea, formed a monophyletic clade within Galeommatoidea.

Keywords: Bivalvia, Commensalism, Diversification, Galeommatoidea, Parallel evolution, Symbiosis, Host specialization, Host switching

\footnotetext{
* Correspondence: gotoryutaro@gmail.com

${ }^{1}$ Graduate School of Human and Environmental Studies, Kyoto University,

Yoshida-Nihonmatsu-cho, Sakyo, Kyoto 606-8501, Japan

${ }^{2}$ Department of Marine Ecosystem Dynamics, Atmosphere and Ocean

Research Institute, The University of Tokyo, 5-1-5 Kashiwa-no-ha, Kashiwa,

Chiba 277-8564, Japan

Full list of author information is available at the end of the article
} 


\section{Background}

Symbiotic relationships between animals are ubiquitous and diverse in the sea [1-5] and play an important role in shaping the spatial pattern and structure of marine biodiversity [1-5]. At evolutionary timescales, colonization of novel animal hosts may lead to speciation and thus constitutes a primary process driving the diversification of symbiotic animals [6-8]. Although the pattern and process of host switching in the terrestrial ecosystem have been extensively studied, most notably in herbivore insects [9], little is known about how symbiotic marine organisms expand their host ranges and diversify via host switching.

Bivalves are a group of mollusks that are generally filter feeders and exist in various marine habitats [10]. Among the bivalves, the superfamily Galeommatoidea is unique in terms of its symbiotic association with various benthic and burrowing invertebrates [11,12]. They utilize these hosts as a home or shelter and benefit from the water currents created by the host, which are rich in oxygen and food particles [12]. The host taxa of Galeommatoidea are extremely diverse and include the phyla Porifera, Cnidaria, Brachiopoda, Bryozoa, Annelida, Mollusca, Arthropoda, and Echinodermata [11-13]. The ecological modes of host utilization by Galeommatoidea are also diverse and include ectosymbionts, endosymbionts, and burrow associates [11-13]. Furthermore, Galeommatoidea includes many free-living species that often attach to the undersurfaces of rocks in the intertidal zone $[14,15]$, and some species are capable of active movement on the substrates by using their muscular foot [15]. An intriguing question is how these diverse host associations and lifestyles evolved in this superfamily.

The classification of Galeommatoidea is in a state of flux, mostly likely owing to their reduced, and sometimes highly modified, morphologies associated with symbiotic life. Often more than one family is recognized within the superfamily, but these groupings are usually ill-defined when a range of characters are considered [16]. The most recent classification divides Galeommatoidea into two families, Galeommatidae and Lasaeidae, although there is little morphological support for these families [17]. On the basis of this classification, the previously recognized families Kelliidae and Montacutidae are included in Lasaeidae. Furthermore, recent anatomical and ecological studies suggest that the genera Peregrinamor and Basterotia, which were traditionally classified into Mytiloidea and Cyamioidea, respectively [18], should be included in Galeommatoidea [19,20]. Further investigation is required to resolve these taxonomic issues.

This study aimed to reveal the diversification history of Galeommatoidea and to resolve the taxonomic confusion surrounding this bivalve superfamily. We conducted a molecular phylogenetic analysis using two nuclear ribosomal genes (18S and $28 \mathrm{~S}$ ribosomal DNA) and one nuclear (histone 3, H3) and one mitochondrial (cytochrome oxidase subunit I, COI) protein-coding genes in galeommatoidean bivalves sampled from a broad range of host animals and habitats in the northwest Pacific Ocean. The resulting phylogenetic tree uncovers an unexpectedly dynamic pattern of host switching and ecological specialization in Galeommatoidea.

\section{Results and discussion \\ Molecular phylogenetic analysis}

We collected sequence data for 18S rRNA, 28S rRNA, $\mathrm{H} 3$ and COI genes in 33 galeommatoidean species belonging to 25 genera and two families, five putative galeommatoidean species belonging to Peregrinamor and Basterotia, and eight outgroup species for the molecular phylogenetic analysis (Table 1). To examine whether Peregrinamor and Basterotia do belong to Galeommatoidea, we selected eight outgroup species representing a range of lineages within Heterodonta, to which Galeommatoidea belongs. We also included three nonheterodont species representing each of three nonheterodont orders to root the entire heterodont tree. All sequences were newly obtained in this study except for the sequences of three non-heterodont species (Additional file 1). Ingroup specimens included 13 free-living species and 25 symbiotic species associated with the crustacean, echinoid, holothurian, cnidarian, sipunculan, and echiuran animal groups (Figure 1; Table 1).

Phylogenetic analysis based on the combined data $(18 \mathrm{~S}+28 \mathrm{~S}+\mathrm{COI}+\mathrm{H} 3$; Additional file 2) suggests that the currently circumscribed Galeommatoidea is not monophyletic and includes Peregrinamor and Basterotia (Figure 2). The expanded Galeommatoidea with the above two genera was strongly supported as a monophyletic group and consists of at least six major clades, most of which are supported by high clade support (Figure 2). However, the relationships among these clades received low support and remained obscure (Figure 2). Notably, the branches leading to Neaeromya and the three species of Basterotia are especially long, which likely further complicates the recovery of branching order among these major lineages. Thus, while we consider that the monophyly of each of the six major clades is supported, the relationships among these clades must be viewed with caution. The seemingly high Bayesian posterior probability values at higher nodes should also be taken with caution because Bayesian posterior probabilities often produce overcredible results when compared with bootstrap analyses [21-23].

\section{Taxonomic classification of the extant Galeommatoidea}

Our molecular phylogenetic analysis suggests that Galeommatoidea includes Basterotia and Peregrinamor, 
Table 1 Sampling information for the specimens used in this study

\begin{tabular}{|c|c|c|c|c|c|c|}
\hline Superfamily & Family & Species & Life style & Host species & Host taxon & Host utilization/ habitat \\
\hline \multirow[t]{33}{*}{ Galeommatoidea } & Galeommatidae & Divariscintilla toyohiwakensis & Symbiotic & Acanthosquilla acanthocarpus & Mantis shrimp (Arthropoda) & Inside the host burrow \\
\hline & & Ephippodonta gigas & Symbiotic & Callianidea typa & Thalassinidean shrimp (Arthropoda) & Inside the host burrow \\
\hline & & Galeomma sp. & Free-living & - & - & On the undersurface of rocks \\
\hline & & Pseudogaleomma sp. & Free-living & - & - & On the undersurface of rocks \\
\hline & & Scintilla rosea & Free-living & - & - & On the undersurface of rocks \\
\hline & & Scintilla aff. hydatina & Free-living & - & - & On the undersurface of rocks \\
\hline & & Scintilla sp.1 & Free-living & - & - & On the undersurface of rocks \\
\hline & & Scintilla sp.2 & Free-living & - & - & On the undersurface of rocks \\
\hline & & Scintillona stigmatica & Symbiotic & Brissus latecarinatus & Heart urchin (Echinodermata) & On the host body \\
\hline & Lasaeidae & Anisodevonia ohshimai & Symbiotic & Patinapta ooplax & Sea cucumber (Echinodermata) & On the host body \\
\hline & & Arthritica japonica & Symbiotic & Xenophthalmus pinnotheroides & Intertidal crab (Arthropoda) & On the host body \\
\hline & & Byssobornia yamakwai & Symbiotic & Ochetostoma erythrogrammon & Spoon worm (Echiura) & Inside the host burrow \\
\hline & & Curvemysella paula & Symbiotic & Spiropagurus spiriger & Hermit crab (Arthropoda) & Inside the shell carried by the host \\
\hline & & Devonia semperi & Symbiotic & Protankyra bidentata & Sea cucumber (Echinodermata) & On the host body \\
\hline & & Entovalva lessonothuriae & Symbiotic & Holothuria (Lessonothuria) pardalis & Sea cucumber (Echinodermata) & Inside the host esophagus \\
\hline & & Kellia porculus & Free-living & - & - & In the crevice of dead corals \\
\hline & & Lasaea undulata & Free-living & - & - & In the crevice of rocks \\
\hline & & Litigiella pacifica & Symbiotic & Sipunculus nudus & Peanut worm (Sipuncula) & On the host body \\
\hline & & Melliteryx puncticulata & Free-living & - & - & On the undersurface of rocks \\
\hline & & Montacutona sp. & Symbiotic & Cerianthus filiformis & Sea anemone (Cnidaria) & On the host body \\
\hline & & Mysella aff. bidentata & Free-living & - & - & In sand sediment \\
\hline & & Neaeromya rugifera & Symbiotic & Upogebia pugettensis & Thalassinidean shrimp (Arthropoda) & On the host body \\
\hline & & Nipponomontacuta actinariophila & Symbiotic & Telmatactis sp. & Sea anemone (Cnidaria) & On the host body \\
\hline & & Nipponomysella oblongata & Free-living & - & - & In sand sediment \\
\hline & & Nipponomysella subtruncata & Symbiotic & Siphonosoma cumanense & Peanut worm (Sipuncula) & On the host body \\
\hline & & Paraborniola matsumotoi & Free-living & - & - & On the undersurface of rocks \\
\hline & & Peregrinamor gastrochaenans & Symbiotic & Upogebia carinicauda & Thalassinidean shrimp (Arthropoda) & On the host body \\
\hline & & Peregrinamor ohshimai & Symbiotic & Upogebia major & Thalassinidean shrimp (Arthropoda) & On the host body \\
\hline & & Pseudopythina ochetostomae & Symbiotic & Listriolobus sorbillans & Spoon worm (Echiura) & Inside the host burrow \\
\hline & & Pseudopythina macrophthalmensis & Symbiotic & Macrophthalmus sp. & Intertidal crab (Arthropoda) & On the host body \\
\hline & & Pseudopythina subsinuata & Symbiotic & Oratosquilla oratoria & Mantis shrimp (Arthropoda) & On the host body \\
\hline & & Pseudopythina aff. ariake & Symbiotic & Protankyra bidentata & Sea cucumber (Echinodermata) & Inside the host burrow \\
\hline & & Pseudopythina aff. nodosa & Symbiotic & Siphonosoma cumanense & Peanut worm (Sipuncula) & On the host body \\
\hline
\end{tabular}


Table 1 Sampling information for the specimens used in this study (Continued)

\begin{tabular}{|c|c|c|c|c|c|c|}
\hline & & Pythina deshayesiana & Free-living & - & - & On the undersurface of rocks \\
\hline & & Salpocola philippinensis & Symbiotic & Sipunculus nudus & Peanut worm (Sipuncula) & On the host body \\
\hline \multirow[t]{3}{*}{ Cyamioidea } & Basterotiidae & Basterotia carinata & Symbiotic & Ochetostoma erythrogrammon & Spoon worm (Echiura) & Inside the host burrow \\
\hline & & Basterotia gouldi & Symbiotic & Ikedosoma gogoshimense & Spoon worm (Echiura) & Inside the host burrow \\
\hline & & Basterotia sp. & Symbiotic & Ochetostoma erythrogrammon & Spoon worm (Echiura) & Inside the host burrow \\
\hline \multirow[t]{8}{*}{ Outgroups } & Solecurtidae & Azorinus minutus & Free-living & - & - & - \\
\hline & Gastrochaenidae & Gastrochaena cuneiformis & Free-living & - & - & - \\
\hline & Veneridae & Irus mitis & Free-living & - & - & - \\
\hline & Mactridae & Meropesta nicobarica & Free-living & - & - & - \\
\hline & Solenidae & Solen strictus & Free-living & - & - & - \\
\hline & Solemyidae & Solemya velum & Free-living & - & - & - \\
\hline & Nuculanidae & Nuculana pella & Free-living & - & - & - \\
\hline & Neotrigoniidae & Neotrigonia margaritacea & Free-living & - & - & - \\
\hline
\end{tabular}




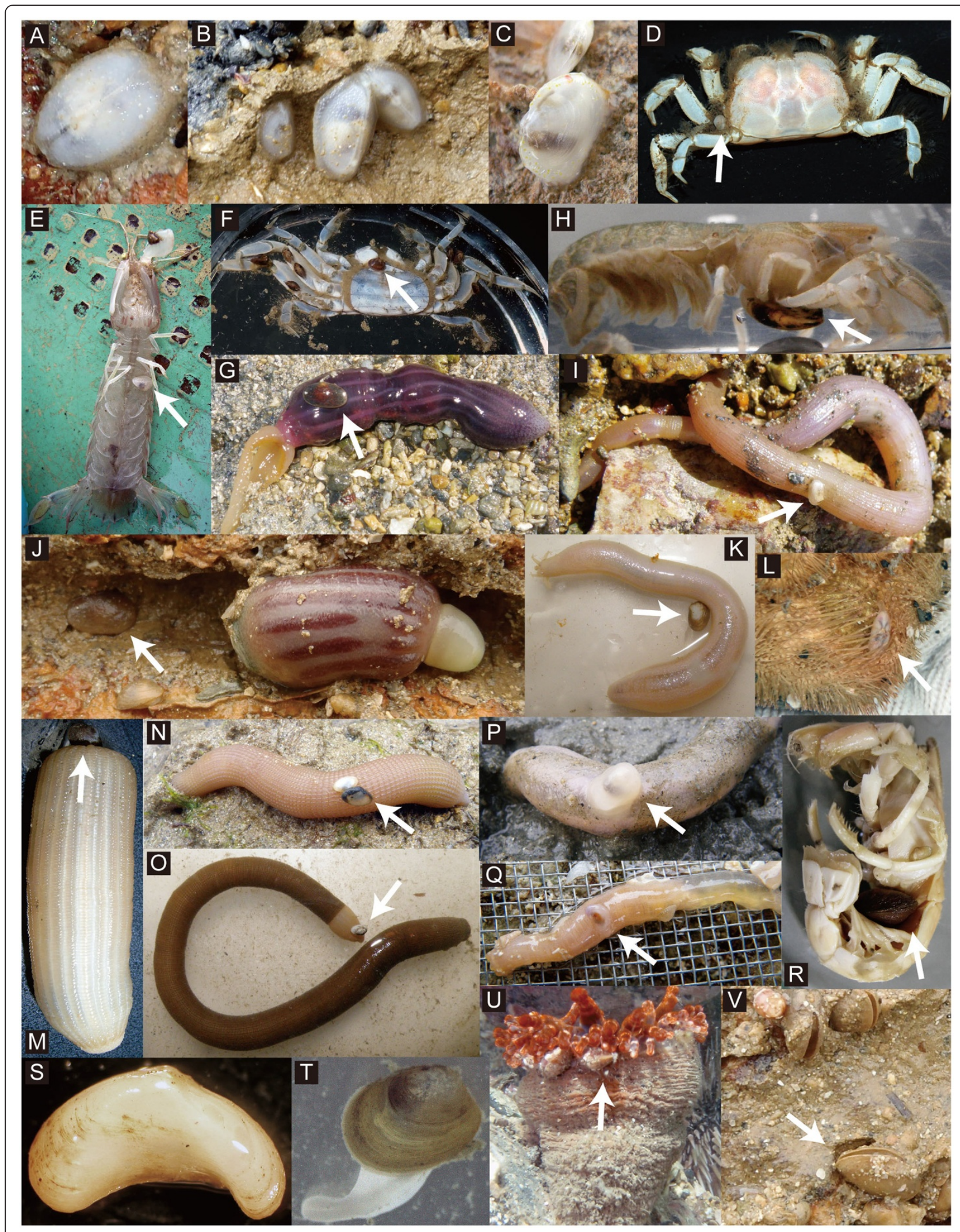

Figure 1 (See legend on next page.) 


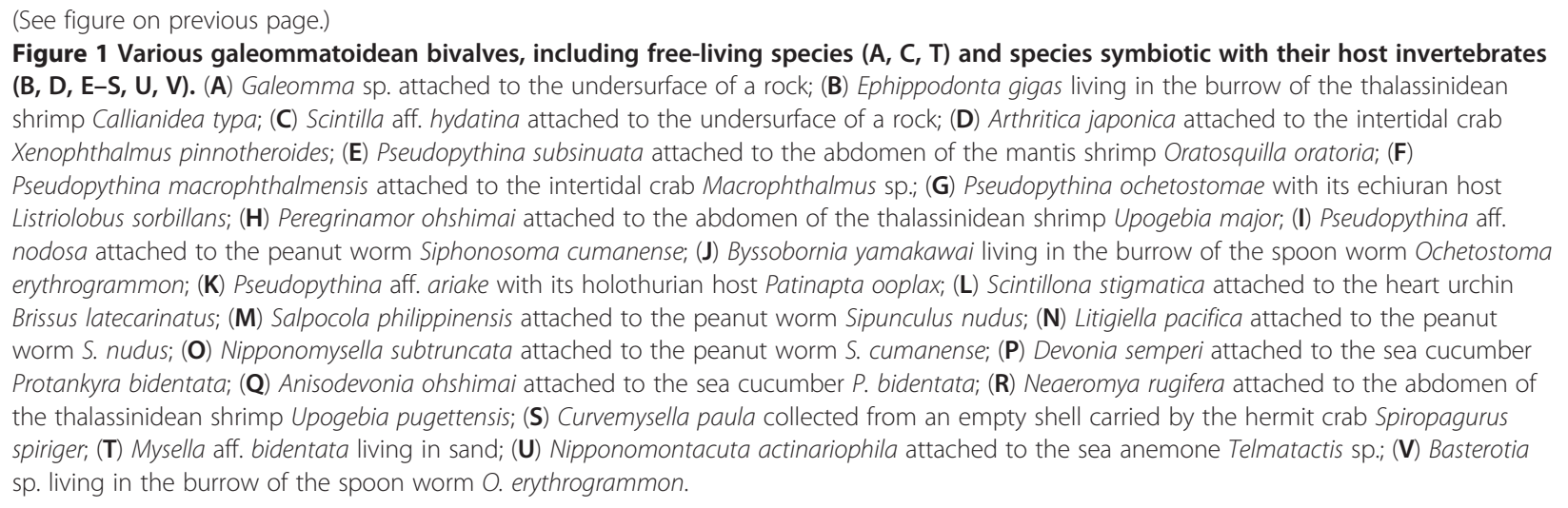

which were previously assigned to Cyamioidea and Mytiloidea, respectively [18]. Basterotia bivalves differ from other galeommatoideans in having the inhalant siphon located posteriorly [20], while Peregrinamor bivalves were included in Mytilidae on the sole basis of superficial resemblance of their shells to those of true Mytilidae [19]. However, our result firmly places these enigmatic genera within Galeommatoidea (Figure 2). Our analysis further reveals that the expanded Galeommatoidea is composed of six major clades. Below we detail major discrepancies between the current classification of Galeommatoidae and phylogenetic relationships obtained in this study. Detailed accounts of the morphology and ecology of each of the major clades are provided in Additional file 3.

Recent provisional classification suggests that Galeommatoidea comprises two families, Galeommatidae and Lasaeidae [17]. However, our results did not support this taxonomic circumscription (Figure 2) and suggested that Galeommatidae and Lasaeidae are polyphyletic (Figure 2). Except for Scintillona stigmatica, the members of the family Galeommatidae were grouped into Clade 1, which also included several lasaeid species (Figure 2), whereas the members of Lasaeidae were divided into six major clades (Figure 2). Lasaeidae was previously divided into several families, namely Lasaeidae, Kellidae, and Montacutidae [18]. However, these previously proposed families were also each non-monophyletic and included genera that were separated into different major clades (Figure 2). These results suggest that the previous family-level classification of Galeommatoidea does not correspond to any of the well-supported clades recovered in our molecular phylogenetic analysis. Furthermore, according to our results, some of the previous genus-level classifications were also not supported. For example, Scintilla and Nipponomysella are polyphyletic (Figure 2). Yet, the discrepancies between the traditional classification and the results of our molecular phylogenetic analysis are not unexpected, considering that many members of Galeommatoidea have reduced or highly specialized morphologies associated with symbiotic life, which potentially obscures the historical information contained in their morphology.

\section{Evolutionary pattern of symbiotic lifestyles in Galeommatoidea}

To investigate the evolutionary pattern of symbiotic lifestyles in Galeommatoidea, we mapped information on the lifestyle (symbiotic or free-living), host taxon, and host association mode of each galeommatoidean species onto the phylogenetic tree (Figure 3). The host organisms we recorded in this study were consistent with those reported in previous studies (Additional file 4), except for Pseudopythina aff. nodosa and Nipponomontacuta actinariophila. The host organism of the latter species was misidentified in the original paper [24]; we obtained $N$. actinariophila from the sea anemone Telmatactis sp., which conforms to more recent records.

Clades 1 and 2 each comprise both free-living and symbiotic species, whereas Clades 3-6 consist of only symbiotic species (Figure 3). The approximately unbiased (AU) test [25] rejected the hypothesis that free-living or symbiotic species are monophyletic in Galeommatoidea $(P<0.0001$, Additional file $5 \mathrm{~b})$, suggesting that transitions between free-living and symbiotic lifestyles occurred multiple times in this bivalve group. Associations with crustaceans, holothurians, sipunculans, and echiurans are each found in multiple major clades (Figure 3). The AU tests also rejected the hypothesis that species with same host taxa are monophyletic (all $P$ values $<$ 0.0001, Additional file $5 \mathrm{c}-\mathrm{f}$ ), suggesting that host specialization to these animal groups likely occurred multiple times independently in Galeommatoidea. In addition, species having very similar modes of physical attachment to the hosts were seen in different major clades (Figure 3). For example, the bivalves attached to the abdomen of thalassinidean shrimps were divided into 


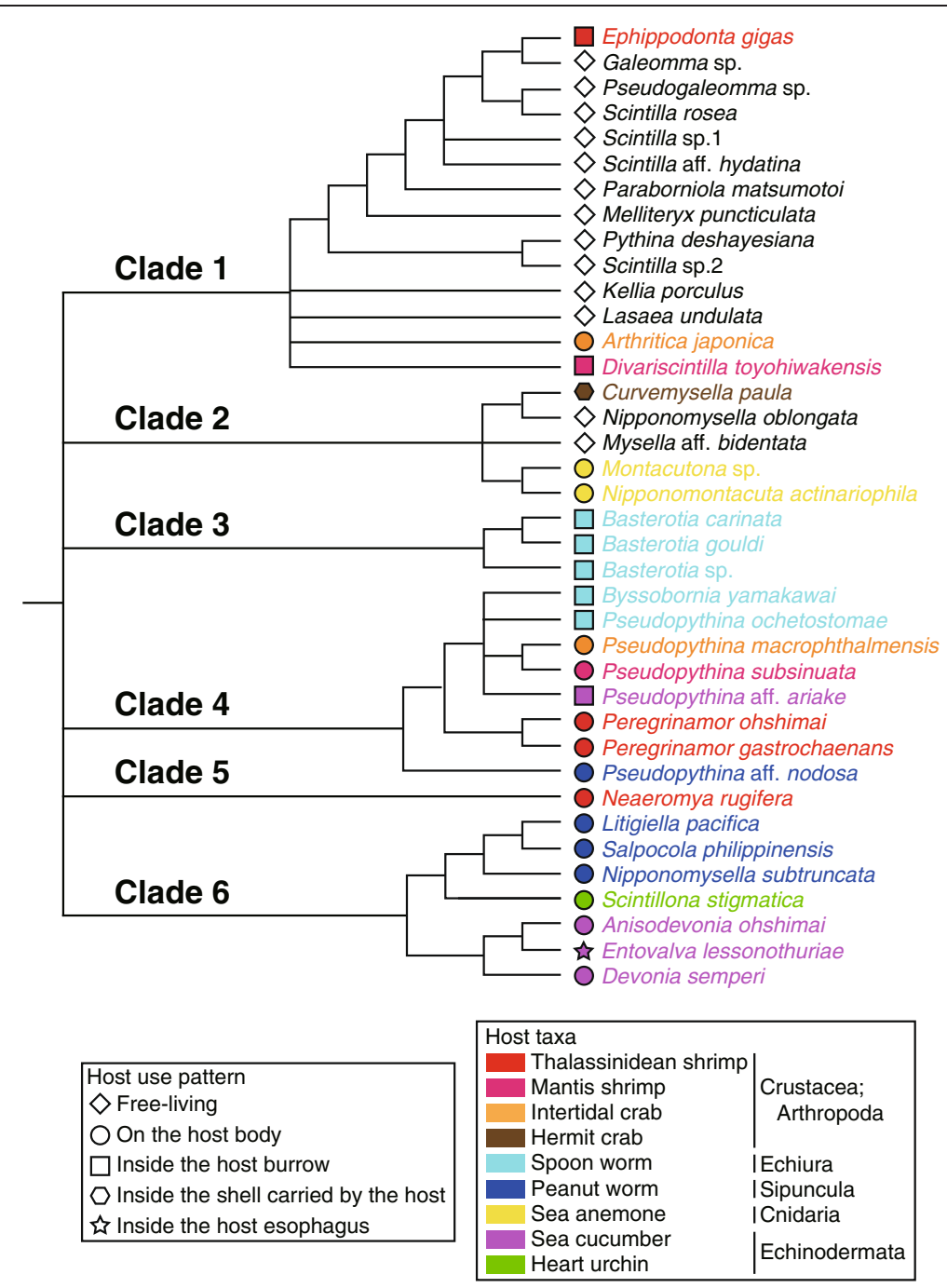

Figure 3 The modified maximum-likelihood tree of Galeommatoidea based on the combined dataset of 18S, 28S, H3 and COI genes. Branches supported by $<65 \%$ maximum-likelihood bootstrap support or $<90 \%$ Bayesian posterior probability values are collapsed. The color and shape of each symbol indicates the host taxon and host use pattern, respectively.

Clades 4 and 5 (Figure 3), and those attached to the body of intertidal crabs were also divided into Clades 1 and 4 . These results were also supported by AU tests (all $P$ values $<0.0001$, Additional file $5 \mathrm{~g}-\mathrm{h}$ ). The hypothesis that the species symbiotic with crustaceans in Clade 1 are monophyletic was also rejected $(P<0.0001$, Additional file 5i), whereas this was not the case in Clade $4 \quad(P=0.065$; Additional file $5 \mathrm{j})$. These results suggest that the gain and/or loss of symbiotic association with crustaceans likely occurred multiple times at least in Clade 1. Although the AU test does not account for uncertainty in phylogenetic estimation, all the strongly rejected tests concern species belonging to different major clades, each with high statistical support, indicating that our conclusions are unlikely affected by phylogenetic uncertainty.
Clades 2, 4 and 6 each includes species utilizing hosts from different animal phyla (Figure 3), suggesting that interphylum host switches occurred repeatedly even within these major clades. In contrast, Clades 1, 3 and 5 each includes species symbiotic with a single phylum (Figure 3).

The ecological modes of host associations are diverse in the Galeommatoidea [11-13,20]. We categorized host association modes into four types: ectosymbiotic on the host body, living inside the host burrow, endosymbiotic inside the host esophagus, and living inside the shells carried by host hermit crabs (Table 1). The former two are the predominant host use patterns in Galeommatoidea (Table 1), whereas the latter two are each found in only a single species. According to the phylogenetic tree (Figure 3), the ectosymbiotic species belonged to five 
major clades, whereas burrow associates belonged to four major clades. The AU tests rejected the hypothesis that ectosymbiotic species or burrow associates are monophyletic (both $P$ values $<0.0001$, Additional file $5 \mathrm{k}, \mathrm{l}$ ), suggesting that there have been repeated shifts between these two modes of host utilization in this bivalve superfamily.

Parallel evolution of host associations in Galeommatoidea Symbiotic associations with crustaceans, holothurians, sipunculans, and echiurans occurred multiple times independently within Galeommatoidea (Figure 3). Below, we compare the groups that independently established symbiotic associations with the same animal groups to better understand the evolution of host associations in Galeommatoidea.

\section{Crustacea}

Symbiotic associations with crustaceans were found in Clades 1, 2, 4 and 5 (Figure 3). Clade 1 includes Ephippodonta gigas that lives in the burrows of thalassinidean shrimps [15] (Figure 1B), Divariscintilla toyohiwakensis that lives in the burrows of mantis shrimps [26], and Arthritica japonica that attaches directly onto the body surface of intertidal crabs [27] (Figure 1D). Clade 2 includes Curvemysella paula that lives inside shells carried by hermit crabs $[12,28]$ (Figure $1 S$ ). Clade 4 includes two Pseudopythina and two Peregrinamor species that attach directly onto the body surface of upogebid shrimps, mantis shrimps, or intertidal crabs $[12,19]$ (Figure 1E, F, H). Clade 5 includes Neaeromya rugifera that attaches onto the abdomen of upogebid shrimps [29,30] (Figure 1R).

Interestingly, Peregrinamor from Clade 4 and Neaeromya from Clade 5 both attach to the abdomen of upogebid shrimps [19,29-31] (Figure 1H, R). The former is distributed in East Asia, and the latter is distributed in North America; thus, similar symbiotic associations with upogebid shrimps likely originated independently in separate geographic locations. Peregrinamor bivalves have evolved remarkable behavioral adaptations to maintain the correct location on the individual Upogebia host through ecdysis events [32]. However, it is unknown whether $N$. rugifera shows a similar behavioral adaptation.

Additionally, A. japonica from Clade 1 and Pseudopythina macrophthalmensis from Clade 4 both attach onto the body surface of intertidal crabs [12,27] (Figure 1D, F). The former is associated with Xenophthalmus pinnotheroides in the Seto Inland Sea, Japan [27], and the latter with various species of Macrophthalmus in subtropical intertidal flats of East Asia [12]. Each of these bivalve species has a smaller body than other closely related species within the same clade. Although its adaptive significance is unknown, such a reduction in size may be related to the ectosymbiotic association with host intertidal crabs.

\section{Holothuroidea}

Symbiotic associations with holothurians were found in Clades 4 and 6. Clade 4 includes Pseudopythina aff. ariake, which attaches to the burrow walls of the host holothurian [12] (Figure 1K), whereas Clade 6 includes Devonia semperi and Anisodevonia ohshimai, which attach to the body surface of the host holothurian [12,33] (Figure 1P, Q), and Entovalva lessonothuriae, which lives inside the esophagus of the host holothurian [33]. In the Seto Inland Sea, Japan, Devonia semperi and $P$. aff. ariake are both associated with Protankyra bidentata and often co-occur sympatrically in the same P. bidentata burrow (Goto, Ishikawa \& Hamamura, unpublished data).

\section{Echiura}

Symbiotic associations with echiurans were found in Clades 3 and 4 . Clade 3 includes three species of Basterotia (Figure 1V), whereas Clade 4 includes Byssobornia yamakawai and Pseudopythina ochetostomae (Figure 1G, $\mathrm{J})$. All of these live in the echiuran burrow but in markedly different ways $[12,20,34]$. The former three species embed their body into the burrow wall, gaping their posterior aperture into the burrow lumen [20,34] (Figure $1 \mathrm{~V}$ ), whereas the latter two live in the narrow space between the host body and burrow wall $[12,34]$ (Figure 1G, J). Basterotia sp. (Clade 3) and Byssobornia yamakawai (Clade 4) often co-occur in the same Ochetostoma erythrogrammon burrow in the Ryukyu Islands, Japan [34].

\section{Sipuncula}

Symbiotic associations with sipunculans were found in Clades 4 and 6. Clade 4 includes Pseudopythina aff. nodosa that attaches directly to the body surface of host sipunculans [12] (Figure 1I), whereas Clade 6 includes Salpocola philippinensis, Nipponomysella subtruncata and Litigiella pacifica, all of which also attach to the body surface of host sipunculans [12,35-37] (Figure 1M-O). Pseudopythina aff. nodosa (Clade 4) and N. subtruncata (Clade 6) both attach to the body surface of the same sipunculan species, Siphonosoma cumanense (Figure 1I, O).

Frequent interphylum host switching in Galeommatoidea In most parasitic organisms, phylogenetic tests demonstrate that host associations are generally conserved across the phylogeny and that switches between distantly related hosts are relatively infrequent [38-42]. In contrast, we found multiple possible instances of host switching between different phyla by galeommatoidean bivalves (Figure 3), raising the question as to what 
factors promote such a pattern of host switching in this superfamily.

The predominant mode of host switching in parasitic organisms is that between closely related hosts [38-42]. This is because parasites are under strong pressure to overcome host defenses, and switches to phylogenetically distant hosts likely require entirely new sets of anti-defense adaptations. Parasitic life also involves exploitation of nutrients from host organisms. Thus, parasites undergoing host shift must adapt to drastic changes in the nutrients they derive from the new host. These and other ecological conditions probably constrain the host range of parasitic organisms and make it difficult to switch between distantly related hosts (e.g., across phyla). In contrast, the symbiotic galeommatoideans are predominantly filter feeders and do not depend directly on their hosts for nutrients, although they indirectly benefit from the water currents created by the host [12]. Furthermore, while symbiotic galeommatoideans benefit greatly from being associated with their host organisms, they usually cause little or no harm to their hosts. In fact, there are no known host defense mechanisms that specifically target these symbionts, although the bivalves themselves have evolved adaptations to stay cryptic on the host body or inside the host burrow. Thus, the commensal lifestyle of these bivalves probably allows them to switch hosts without a need to adapt to host physiology or evolve other defense mechanisms. Overall, these ecological attributes of galeommatoidean bivalves probably made them frequent colonizers of various marine invertebrate hosts.

\section{Remaining issues and directions for future research}

Our results suggest that host switching played an important role in the diversification of Galeommatoidea. However, this superfamily also includes a large number of free-living species [15], whose diversification obviously did not occur by host switching. In addition, several well-supported clades of symbiotic bivalves include species that share closely related hosts, suggesting that mechanisms other than host switching have also been important in the evolution of these bivalves. For example, the closely-related Anisodevonia ohshimai, Entovalva lessonothuriae and Devonia semperi in Clade 6 all utilize sea cucumbers as hosts, and thus, cospeciation (i.e., parallel speciation of hosts and parasites) and/or shift in the mode of host utilization may have been the major driver of speciation. Similarly, Basterotia species (Calde 3) commonly share the same echiura host species [34], indicating that host switches are unlikely to have occurred in this genus. Clarifying alternative mechanisms of speciation other than host switching is therefore needed to gain a full understanding of the diversification history of Galeommatoidea.
Overall, our molecular phylogenetic analysis has greatly progressed our understanding of the phylogenetic relationships within Galeommatoidea. However, the relationships among the major clades, as well as those within each clade, are still poorly resolved. Inclusion of more species in the analysis and better marker choice are probably needed to obtain higher resolved molecular phylogenies of this bivalve superfamily. Such wellresolved phylogenies can then be used to further test questions such as (1) the direction and frequency of transitions between free-living and symbiotic lifestyles in Galeommatoidea, (2) the relative importance of host switching as compared to other speciation mechanisms, as discussed above, and (3) patterns of morphological, behavioral and physiological specialization/reduction associated with symbiosis with diverse invertebrate hosts.

\section{Conclusions}

The present analysis of nuclear and mitochondrial DNA sequence data is the first comprehensive molecular phylogenetic analysis of the bivalve superfamily Galeommatoidea. The phylogenetic tree suggested the inclusion of Peregrinamor and Basterotia within Galeommatoidea and recovered six major clades within the expanded Galeommatoidea. Symbiotic associations with crustaceans, echiurans, sipunculans, and holothurians were found in multiple major clades, suggesting that host specialization to these animal groups occurred repeatedly in this superfamily. Furthermore, within the same major clades, the associated hosts were often divergent at the phylum level, suggesting that host switching between different phyla occurred repeatedly in Galeommatoidea. The groupings based on molecular phylogeny did not correspond with the extant familial classification; Galeommatidae and Lasaeidae were found to be polyphyletic. Therefore, taxonomic revision of this bivalve superfamily is needed.

\section{Methods}

\section{Sampling}

We collected 38 specimens from 33 galeommatoidean and five putative galeommatoidean species belonging to 27 genera and three families. For outgroups, we sampled five species belonging to five non-galeommatoidean families within Heterodonta (Table 1). All specimens were collected in southwestern Japan with the exception of Neaeromya rugifera, which was collected in Oregon, USA (see Additional file 1). We also included the sequence data of three non-heterodont outgroup species that were available in GenBank (Additional file 1) to root the entire heterodont phylogeny. 


\section{Molecular methods}

Total DNA was isolated following a previously described method [43]. Adductor muscle tissue was homogenized in $800 \mu \mathrm{l}$ lysis buffer and incubated at $55^{\circ} \mathrm{C}$ overnight, after which $80 \mu$ l saturated potassium chloride was added to the lysate. This solution was incubated for $5 \mathrm{~min}$ on ice and then centrifuged for $10 \mathrm{~min}$. The supernatant $(700 \mu \mathrm{l})$ was transferred to a new tube, cleaned once with a phenol/ chloroform solution, and precipitated with an equal volume of 2-propanol. The DNA pellet was rinsed with 70\% ethanol, vacuum-dried, and dissolved in $100 \mu \mathrm{l}$ TE buffer.

We sequenced the fragments of the nuclear $18 \mathrm{~S}$ and 28S ribosomal RNA (rRNA), H3 and the mitochondrial COI genes. Polymerase chain reactions (PCRs) were used to amplify $\sim 1700 \mathrm{bp}$ of $18 \mathrm{~S}$ rRNA, $\sim 1000 \mathrm{bp}$ of $28 \mathrm{~S}$ rRNA, $\sim 350$ bp of $\mathrm{H} 3$ and $\sim 700$ bp of COI. Amplifications were performed in $20 \mu \mathrm{l}$ mixtures consisting of $0.4 \mu \mathrm{l}$ of forward and reverse primers (primer sequences are provided in Additional file 6), $1.6 \mu \mathrm{l}$ of dNTP, $2.0 \mu \mathrm{l}$ of ExTaq buffer, $0.1 \mu \mathrm{l}$ of ExTaq polymerase (TaKaRa, Otsu, Japan), and $15.1 \mu \mathrm{l}$ of distilled water. Thermal cycling was performed with an initial denaturation for $3 \mathrm{~min}$ at $94^{\circ} \mathrm{C}$, followed by 30 cycles of $30 \mathrm{~s}$ at $94^{\circ} \mathrm{C}, 30 \mathrm{~s}$ at a gene-specific annealing temperature (Additional file 6), and $2 \mathrm{~min}$ at $72^{\circ} \mathrm{C}$, with a final $3 \mathrm{~min}$ extension at $72^{\circ} \mathrm{C}$. The sequencing reaction was performed using the PCR primers and internal primers (Additional file 6) and the BigDye Terminator Cycle Sequencing Ready Reaction Kit (Applied Biosystems, Foster City, CA) and electrophoresed on an ABI 3130 sequencer (Applied Biosystems). The obtained sequences have been deposited in the DDBJ/EMBL/GenBank databases with accession numbers AB714745-AB714907 (Additional file 1).

\section{Phylogenetic analysis}

Sequences of the 18S, 28S, H3 and COI genes were aligned using Muscle [44] as implemented in the software Seaview $[45,46]$ under default settings. The alignments of $\mathrm{H} 3$ and $\mathrm{COI}$ sequences did not require insertion of gaps and was therefore unambiguous. We used the software Gblocks v0.91b [47-49] to delimit ambiguously aligned regions in the $18 \mathrm{~S}$ and $28 \mathrm{~S}$ alignments (Additional file 7), and the following phylogenetic analyses were conducted with and without alignmentambiguous regions. The full $18 \mathrm{~S}$ and $28 \mathrm{~S}$ alignments contained 474 and 282 variable sites, respectively, and 453 and 249 variable sites when alignment-ambiguous regions were excluded. The $\mathrm{H} 3$ and $\mathrm{COI}$ alignments contained 87 and 297 variable sites, respectively, indicating that despite their short sequence lengths, they contain comparable amount of information as the $18 \mathrm{~S}$ and $28 \mathrm{~S}$ partitions. Because the initial phylogenetic analyses of individual genes did not produce essentially different results
(Additional file 8), we focused our analyses on the combined four-gene data set, which will be described below.

Phylogenetic trees were obtained by the maximumlikelihood (ML) and Bayesian methods. For the ML analysis, model selection and tree search were conducted using the TreeFinder program [50,51]. The robustness of the ML tree was validated by bootstrap analysis with 1000 replications using the same program.

Bayesian analyses were performed using MrBayes 3.1.2 [52] with substitution models chosen using MrModeltest 2.3 [53]. In the combined data set, substitution parameters were estimated separately for each gene using the 'unlink' command. Two independent runs of Metropolis-coupled Markov chain Monte Carlo were performed simultaneously, sampling trees every 100 generations and calculating the average standard deviation of split frequencies every 1000 generations. Using the 'stoprule' option, analyses were continued until the average standard deviation of split frequencies dropped below 0.01 , at which point the two chains were considered to have achieved convergence. Because the average standard deviation of split frequencies was calculated based on the last $75 \%$ of the samples, we discarded the initial $25 \%$ of the sampled trees as burn-in. We confirmed that analyses reached stationarity well before the burn-in period by plotting the ln-likelihood of the sampled trees against generation time.

\section{Mapping of host taxon and mode of host utilization}

To evaluate the evolutionary history of symbiotic life in Galeommatoidea, we mapped information on the lifestyle (symbiotic or free-living), host taxon, and mode of host utilization of each galeommatoidean species onto the phylogenetic tree. Host information was based on our sampling data. We checked our sampling data against previously available information on host association for each bivalve species (see Additional file 4) to confirm the validity of our observations of their lifestyle and host taxon.

\section{Approximately unbiased (AU) test}

We tested the hypothesis of monophyly of species sharing the same lifestyle (free-living and symbiotic), modes of host utilization, or host taxa using the AU test [25]. The analyses were done using the combined four-gene data set. The alternative trees were obtained by ML heuristic search under the topological constraint (Additional file 5), and the AU test was conducted based on 1,000,000 replications using Treefinder [50,51].

\section{Additional files}

Additional file 1: Sampling information of the specimens used in this study. 
Additional file 2: Combined molecular data set. The data provided includes an alignment of the four concatenated molecular data partitions (18S, 28S, H3 and COI).

Additional file 3: Morphological and ecological accounts for each clade within Galeommatoidea.

Additional file 4: Host information of each galeommatoidean species sampled.

Additional file 5: The results of approximately unbiased (AU) tests. Additional file 6: Information on primers and PCR conditions used in this study.

Additional file 7: Information on sequence alignment and models of sequence evolution for the maximum likelihood analysis.

Additional file 8: Maximum likelihood tree of Galeommatoidea based on each partition. Numbers above branches indicate maximumlikelihood bootstrap support values followed by Bayesian posterior probabilities. Especially long branches are broken down to fit the page.

\section{Competing interests}

The authors declared that they have no competing interests.

\section{Authors' contributions}

RG designed the study, carried out the field survey, performed the molecular sequencing and the phylogenetic analysis, and drafted the manuscript. AK performed the phylogenetic analysis and drafted the manuscript. $\mathrm{HI}$ and $\mathrm{YH}$ carried out the field survey and collected the specimens. MK participated in the design of the study and drafted the manuscript. All authors read and approved the final manuscript

\section{Acknowledgements}

We thanked G. Itani, Y. Kameda, T. Okamoto, R. Tsubaki, and Y. Yamane for sample collection; and Y. Kano and A. S. Tanabe for data analysis. This work was supported by a grant from the Japan Society for the Promotion of Science to MK and a grant from the Japan Society for the Promotion of Science Research Fellowships for Young Scientists to RG.

\section{Author details}

'Graduate School of Human and Environmental Studies, Kyoto University, Yoshida-Nihonmatsu-cho, Sakyo, Kyoto 606-8501, Japan. ${ }^{2}$ Department of Marine Ecosystem Dynamics, Atmosphere and Ocean Research Institute, The University of Tokyo, 5-1-5 Kashiwa-no-ha, Kashiwa, Chiba 277-8564, Japan. ${ }^{3}$ Center for Ecological Research, Kyoto University, 2-509-3 Hirano, Otsu, Shiga 520-2113, Japan. ${ }^{4}$ 965-1 Kawachi-ko, Uwajima, Ehime 798-0075, Japan. ${ }^{5} 14-16$ Yakeyama-Hibarigaoka-cho, Kure, Hiroshima 737-0901, Japan.

Received: 13 June 2012 Accepted: 30 August 2012

Published: 6 September 2012

\section{References}

1. Morton B: Partnerships in the sea: Hong Kong's marine symbioses. Hong Kong: Hong Kong University Press; 1998.

2. Nybbaken JW, Bertness M: Marine biology: an ecological approach. 6th edition. San Francisco: The Benjamin/Cummings Pub Co; 2004.

3. Williams JD, McDermott JJ: Hermit crab biocoenoses: worldwide review of the diversity and natural history of hermit crab associates. J Exp Mar Biol Ecol 2004, 305:1-128.

4. Anker A, Murina GV, Lira C, Vera Caripe JA, Palmer AR, Jeng MS: Macrofauna associated with echiuran burrows: a review with new observations of the innkeeper worm, Ochetostoma erythrogrammon Leuckart and Rüppel, in Venezuela. Zool Stud 2005, 44:157-190.

5. Macdonald KS, Ríos R, Duffy JM: Biodiversity, host specificity, and dominance by eusocial species among sponge-dwelling shrimp on the Belize Barrier Reef. Divers Distrib 2006, 12:165-178.

6. Duffy JE: Resource-associated population subdivision in a symbiotic coral reef shrimp. Evolution 1996, 50:360-373.

7. Munday PL, van Herwerden L, Dudgeon CL: Evidence for sympatric speciation by host shift in the sea. Curr Biol 2004, 14:1498-1504.

8. Faucci A, Toonen RJ, Hadfield MG: Host shift and speciation in a coral-feeding nudibranch. Proc Roy Soc B 2007, 274:111-119.
9. Coyne JA, Orr HA: Speciation. Massachusetts: Sinauer Associates; 2004.

10. Morton B, Prezant RS, Wilson B: Class Bivalvia. In Mollusca: The Southern Synthesis. Fauna of Australia. Volume 5. Part A. Edited by Beesely PL, Ross GJB, Wells A. Melbourne: CSIRO Publishing; 1998:195-234.

11. Boss KJ: Symbiotic erycinacean bivalves. Malacologia 1965, 3:183-195.

12. Morton B, Scott PH: The Hong Kong Galeommatacea (Mollusca: Bivalvia) and their hosts, with descriptions of new species. Asian Mar Biol 1989, 6:129-160.

13. Savazzi E: A review of symbiosis in the Bivalvia, with special attention to macrosymbiosis. Paleontol Res 2001, 5:55-73.

14. Morton B: The biology and functional morphology of Galeomma (Paralepida) takii (Bivalvia: Leptonaceae). J Zool 1973, 169:133-150.

15. Lützen J, Nielsen C: Galeommatid bivalves from Phuket, Thailand. Zool J Linn Soc 2005, 144:261-306.

16. Ponder WF: Superfamily Galeommatoidea. In Mollusca: The Southern Synthesis. Fauna of Australia. Volume 5. Part B. Edited by Beesely PL, Ross GJB, Wells A. Melbourne: CSIRO Publishing; 1998:316-318.

17. Bieler R, Carter GJ, Coan EV: Classification of bivalve families. Malacologia 2010, 52:113-184

18. Vaught KC: A classification of the living Mollusca. Melborne: American Malacologists Incorporation; 1989

19. Kato M, Itani G: Commensalism of a bivalve, Peregrinamor ohshimai, with a thalassinidean burrowing shrimp, Upogebia major. J Mar Biol Assoc UK 1995, 75:941-947.

20. Goto R, Hamamura Y, Kato M: Morphological and ecological adaptation of Basterotia bivalves (Galeommatoidea: Sportellidae) to symbiotic association with burrowing echiuran worms. Zool Sci 2011, 28:225-234

21. Huelsenbeck JP, Rannala B: Frequentist properties of Bayesian posterior probabilities of phylogenetic trees under simple and complex substitution models. Syst Biol 1994, 53:904-913.

22. Suzuki Y, Glazko GV, Nei M: Overcredibility of molecular phylogenetics obtained by Bayesian phylogenetics. Proc Nat Acad Sci USA 2002, 99:16138-16143

23. Erixon P, Svennblad B, Britton T, Oxelman B: Reliability of posterior probabilities and bootstrap frequencies in phylogenetics. Syst Biol 2003, 52:665-673.

24. Habe T: Halcampella maxima Hertwig, host of Nopponomontacuta actinariophila Yamamoto \& Habe. Venus 1973, 31:157.

25. Shimodaira $\mathrm{H}$ : An approximately unbiased test of phylogenetic tree selection. Syst Biol 2002, 51:492-508.

26. Yamashita H, Haga T, Lützen J: The bivalve Divariscintilla toyohiwakensis n. sp. (Heterodonta: Galeommatidae) from Japan, a commensal with a mantis shrimp. Venus 2011, 69:123-133.

27. Lützen J, Takahashi T: Arthritica japonica, sp. nov. (Bivalvia: Galeommatoidea: Leptonidae), a commensal with the pinnotherid crab Xenophthalmus pinnotheroides White, 1846. Yuriyagai 2003, 9:11-19.

28. Goto R, Hamamura $Y$, Kato M: Obligate commensalism of Curvemysella paula (Bivalvia: Galeommatidae) with hermit crabs. Mar Biol 2007, 151:1615-1622.

29. Narchi W: On Pseudopythina rugifera (Carpenter, 1864) (Bivalvia). Veliger 1969, 12:43-52.

30. Foighil D: Form, function, and origin of temporary dwarf males in Pseudopythina rugifera (Carpenter, 1864) (Bivalvia: Galeommataceae). Veliger 1985, 27:245-252.

31. Kato M, Itani G: Peregrinamor gastrochaenans (Bivalvia: Mollusca), a new species symbiotic with the thalassinidean shrimp Upogebia carinicauda (Decapoda: Crustacea). Species Divers 2000, 5:309-316.

32. Itani $G$, Kato M, Shirayama $Y$ : Behaviour of the shrimp ectosymbionts, Peregrinamor ohshimai (Mollusca: Bivalvia) and Phyllodurus sp. (Crustacea: Isopoda) through host ecdyses. J Mar Biol Assoc UK 2002, 82:69-78.

33. Kato M: Morphological and ecological adaptations in montacutid bivalves endo- and ecto-symbiotic with holothurians. Can J Zool 1998 76:1403-1410.

34. Goto R, Kato M: Geographic mosaic of mutually exclusive dominance of obligate commensals in symbiotic communities associated with a burrowing echiuran worm. Mar Biol 2012, 159:319-330.

35. Habe T, Kanazawa T: A new commensal bivalve from the Philippines (Montacutidae). Venus 1981, 40:123-125.

36. Lützen J, Takahashi T, Yamaguchi T: Morphology and reproduction of Nipponomysella subtruncata (Yokoyama), a galeommatoidean bivalve 
commensal with the sipunculan Siphonosoma cumanense (Keferstein) in Japan. J Zool 2001, 254:429-440.

37. Lützen J, Kosuge T: Description of the bivalve Litigiella pacifica $\mathrm{n}$. sp. (Heterodonta: Galeommatoidea: Lasaeidae), commensal with sipunculan Sipuculus nudus from the Ryukyu Islands. Japan. Venus 2006, 65:193-202.

38. Ricklefs RE, Fallon SM: Diversification and host switching in avian malaria parasites. Proc Roy Soc B 2002, 269:885-892.

39. Lopez-Vaamonde C, Charles H, Godfray J, Cook JM: Evolutionary dynamics of host-plant use in a genus of leaf-mining moths. Evolution 2003, 57:1804-1821.

40. Hoberg EP, Brooks DR: A macroevolutionary mosaic: episodic hostswitching, geographical colonization and diversification in complex host-parasite systems. J Biogeogr 2008, 35:1533-1550

41. Gómez JM, Verdú M, Perfectti F: Ecological interactions are evolutionary conserved across the entire tree. Nature 2010, 465:918-921.

42. Wiens JJ, Ackerly DD, Allen AP, Anacker BL, Buckley LB, Cornell HV, Damschen El, Jonathan DT, Grytnes J-A, Harrison SP: Niche conservatism as an emerging principle in ecology and conservation biology. Ecol Lett 2010, 13:1310-1324

43. Sokolov PE: An improved method for DNA isolation from mucopolysaccharide-rich molluscan tissues. J Molluscan Stud 2000, 66:573-575.

44. Edgar RC: MUSCLE: multiple sequence sequence alignment with high accuracy and high throughput. Nucl Acids Res 2004, 32:1792-1797.

45. Galtier N, Gouy M, Gautier C: SEAVIEW and PHYLOWIN: two graphic tools for sequence alignment and molecular phylogeny. Comput Appl BiosCi 1996, 12:543-548.

46. Gouy M, Guindon S, Gascuel O: Seaview version 4: a multiplatform graphical user interfacre for sequence alignment and phylogenetic tree building. Molecul Biol Evol 2010, 27:221-224.

47. Castresana J: Selection of conserved blocks from multiple alignments for their use in phylogenetic analysis. Mol Biol Evol 2000, 17:540-552.

48. Talavera G, Castresana J: Improvement of phylogenies after removing divergent and ambiguously aligned blocks from protein sequence alignments. Syst Biol 2007, 56:564-577.

49. Gblocks Server. http://molevol.cmima.csic.es/castresana/Gblocks_server.html.

50. Jobb G: TREEFINDER available from Munich. 2007. www.treefinder.de.

51. Jobb G, Haeseler A, Strimmer K: TREEFINDER: a powerful graphical analysis environment for molecular phylogenetics. BMC Evol Biol 2004, 4:18

52. Ronquist F, Huelsenbeck JP: MRBAYES 3: Bayesian phylogenetic inference under mixed models. Bioinformatics (Oxf) 2003, 19:1572-1574.

53. Nylander JA: MrModeltest v2. Evolutionary Biology Centre: Program distributed by the author. Uppsala University; 2004.

doi:10.1186/1471-2148-12-172

Cite this article as: Goto et al:: Molecular phylogeny of the bivalve superfamily Galeommatoidea (Heterodonta, Veneroida) reveals dynamic evolution of symbiotic lifestyle and interphylum host switching. $B M C$ Evolutionary Biology 2012 12:172.

\section{Submit your next manuscript to BioMed Central and take full advantage of:}

- Convenient online submission

- Thorough peer review

- No space constraints or color figure charges

- Immediate publication on acceptance

- Inclusion in PubMed, CAS, Scopus and Google Scholar

- Research which is freely available for redistribution

Submit your manuscript at www.biomedcentral.com/submit
C Biomed Central 